\title{
The Phoneme and the Phonotype
}

\author{
Olga I. Brodovich* \\ Institute of Foreign Languages \\ 12 Linija Vassilievsky Island, 13, St. Petersburg, 199178, Russia
}

Received 14.12.2015, received in revised form 10.02.2016, accepted 24.02.2016

The paper has as its aim to show that in cases of sound symbolism and onomatopoeia the meaningful entities are not phonemes in the entirety of their phonetic features, but concrete features reflecting the sound-shape or other properties of the object designated. Also shown is the similarity and difference of sound symbolism in a word and that in a (literary) text.

Keywords: iconicity, sound-symbolism, onomatopoeia, sound-shape of a text, the sound-sense correlation.

DOI: 10.17516/1997-1370-2016-9-3-620-624.

Research area: philology.

\section{Introduction}

While the notion of phoneme is well known to all linguists, the term phonotype, being a comparatively new one, stands in need of explanation. It was introduced by professor Stanislav Voronin, the founder of phonosemantics as a branch of the linguistic science sui generis. The term was introduced to designate the principal unit of phonosemantics. Its original terminological shape was phonemotype (vide Voronin, 1969, 12), but it was consequently changed to phonotype (Voronin, 1998, 9), the latter name better suiting the notion in question. The principal object of this paper is to present a more detailed description of the term.

\section{From Phonemotype to Phonotype}

In his paper presented at the Fifteenth Meeting of the Language Origins Society in
Naples in 1999 S. Voronin thus defined the term: Phonotype (acoustic or articulatory) is a speech sound type containing a phonetic feature type (acoustic or articulatory) homeomorphous with (i.e. similar to) the referent feature type (acoustic or non-acoustic) serving as basis for phonoiconic (onomatopoeic or sound-symbolic) nomination. (See also Voronin, 2005, 102-103.)

Although the notion of a phonetic feature is included in this definition almost in passing, as it were, its true significance cannot be overestimated. The earlier term phonemotype suggested the idea that in the building of an iconic word the phoneme acts in its entirety, as the bunch of phonetic features. But it is not so. Consider as example any of the (English) words with the idea of roundedness as the motive for nomination, say coop, bubble, or pompon. The phonemes chosen to form words with this meaning often include

(C) Siberian Federal University. All rights reserved

* Corresponding author E-mail address: olgabrodovich@yandex.ru 
$/ \mathrm{u} /$ - not because it is a back vowel, but only because of its labialised articulation. Alternatively or jointly, such words may contain either $/ \mathrm{p} /$ or /b/ - again only because of their labial quality, while the [+ voice] or the [- voice] feature is in these cases of no importance. So /u/ (and also /o/), $/ \mathrm{p} /$ and $/ \mathrm{b} /$ form the phonotype of labials serving in all languages as a resource for nominating round objects (and also pejoration and some other notions - see, among others, Shamina 1989, Slonitskaya 1987). On the other hand, /b/ may cooperate with $/ \mathrm{d} /$ and $/ \mathrm{g} /$ to form a phonotype of voiced plosives used for designations of loud pulse-sounds, as in the English bang, ding$\boldsymbol{d}$ ong, $\boldsymbol{g}$ ong. Here what matters is their [+ voice] feature and their plosiveness, while the place of articulation (i.e. whether they are labials, dentals or gutturals) is irrelevant. In designations of low sounds $/ \mathrm{u} /$ will be chosen not because of its labialised articulation, but only because it belongs to back vowels. See toot, for example, where, characteristically, it is surrounded not by labials as in the examples above but by dentals (or more precisely by alveolars).

The role of the phonetic feature in the phenomenon of linguistic iconism is witnessed by the wording of the by now classical book by A.Zhuravlev Foneticheskoye znacheniye (The Sense of the Sound) (Zhuravlev, 1974), where the author discusses all his findings in terms of phonetic features, not phonemes. It should be noted, however, that the material objects of his research were what he termed as sound-letters, i.e. the letters of the Russian alphabet AND the sounds they designate. That is to say, what was presented to the informants in the experiments were sounds as they are represented by letters. This explains some rather peculiar findings of the research in question. For example, a stage in the research consisted in presenting the informants with Russian sound-letters to be evaluated in terms of pairs of qualities. One of such pairs was round versus angular. The most "angular" of Russian voiced plosives turned out to be the /g/ sound, while for the /b/ and /d/ sounds this pair of qualities was mostly shown as irrelevant. The plausible explanation for this fact is that the Russian letter for the /g/ sound, namely $\underline{\mathbf{I}}_{\mathbf{2}}$ is indeed angular in shape. Another side of the research in question which detracts from the otherwise extremely valuable data is the fact that in discussing consonants it completely ignores the place of articulation. Now, there is plenty of evidence to show that in many instances of linguistic iconism this feature is crucial. In addition to the examples above we could point out that deictic pronouns regularly, that is in many languages, are formed by dental articulations, where the forward movement of the tongue synesthetically imitates the deictic activity of the hand and/or fingers. Note that whether the phonemes in question belong to plosives or fricatives, or whether they possess the [ + voice] or the [- voice] feature, is irrelevant. It is only the place of articulation of the consonant that matters here.

\section{Iconicity in a text versus iconicity in a word}

So the phonotype is centred around a specific phonetic feature. This, I hope, has been demonstrated above as true for cases of isolated words, i.e. for cases of nomination. But phonetic iconism also exists as a property of a (literary) text. If the unit of phonosemantics is indeed found in the phonotype, it should be equally relevant for investigating cases of sound-symbolism in the text. Let us then take a better look at the similarity and difference between phonetic iconism of an isolated word and that of a text. To do this let us scrutinize a text whose soundshape could justifiably be supposed to be nonarbitrary, say, a piece of poetry. What is chosen here is a poem from the collection of Verses for 
Children by Joseph Brodsky, namely The Song of the Rain. It was written long before the poet's emigration, so it naturally is in Russian. I chose the poetry of Brodsky because he looked down upon intentional use of particular sound-shape of the type that, for instance, E.Poe often used, as rather cheap. Therefore we may safely take it that the choice of sounds in Brodsky's texts was truly unintentional - and therefore if the sounds do show some connection with the meaning of the text, it is objective proof of there being such a thing as meaningful sounds in a literary text.

Ария дождя

Словно сттруны, но живые, наши струи дождевые.

И бренчат на них 무 тумане ветры - старые цыгане.

Целый день гудит гитара от небес до тротуара.

Но не блещет та гитара новизной репертуара.

In the printed variant of the text I have marked the liquids, sonants and the voiced fricatives with the bold face and underlined the voiceless fricatives and affricates. The poem sings a song of the rain as it is often heard in the streets of St.Petersburg, the poet's native town, that is, not a torrent of rain, but a steady drizzle often lasting for hours and hours. Therefore the sound-shape of the text is based on imitating (a) the "liquid" sound of the flow of water and (b) the whispering sound caused by the soft and light drops of water as they strike the walls and window-panes of houses and the pavement. The first function is performed by the liquids, sonants and the voiced fricatives, the second - by the voiceless fricatives and affricates (which in Russian are only voiceless). Now, out of all consonants occurring in the text, i.e. out of 79 instances of consonant use, the first group counts 39 occurrences, which forms $49 \%$ of all consonant sounds in the text, the second group counts 12 occurrences, which gives us another $15 \%$ of all consonant sounds. Thus the 51 occurrences of meaningful consonants form $64 \%$ of all consonant sounds in the text - which should be considered as significant proof of the objective non-arbitrariness of the sound-shape of the poem.

The sounds of the text which are shown to be semantically relevant include - for the first semantic task - the sonants $/ \mathrm{m} /$ (1 instance) and $/ \mathrm{n} /$ (15 instances), the liquids / $/ /$ ( 3 instances) and $/ \mathrm{r} /$ (12 instances) and voiced fricatives $/ \mathrm{v} /$ (5 instances), its palatal pair $/ \mathrm{v}^{\prime} /$ ( 1 instance), $/ \check{z} /$ ( 2 instances) and /z/ (1 instance). For the second semantic task the text uses voiceless fricatives $/ \mathrm{s} /$ (5 instances), $/ \check{\mathrm{s}} /$ (1 instance), /x/ (1 instance), /f/ (1 instance, the de-voiced pair of the $/ \mathrm{v} /$ in в тумане), and voiceless affricates $/ \mathrm{t}^{\prime} /$ (1 instance), /ts/ (2 instances) and $/{ }^{\prime} t /$ (1 instance). Using sonants and liquids to imitate the monotonous sound of endlessly pouring water is self-justifiable, but what should be specially noted is the frequent use of $/ \mathrm{r} /$ in this context. The phoneme $/ \mathrm{r} /$ is here working not through all its features. Its vibrant quality is of no importance for imitating a water-flow, what it exploited here is exclusively its property of a liquid. In the case of the second semantic task performed by sound-imitative devises, important is the [- voice] feature of the fricatives and affricates, which effectively shows the softness of the sound of the St.Petersburg rain and its whispering quality, while the fact that, for instance, / $\mathrm{f} /$ is labio-dental or / $\mathrm{x} /$ is guttural, is here completely immaterial. Another relevant feature of these consonants is that they all are fricatives or contain a fricative as an essential part of their articulation. The principal role of voiceless fricatives for designations of hissing, rustling sounds has been shown by S.Voronin in his 1998 book English Onomatopes: A 
Phonosemantic Classification - as also the fact that in this case the place of articulation is irrelevant.

But there is a very important difference between the motivated shape of individual words and that of a text. Look at the words above with the marked consonants as at individual lexical items, not parts of the text tissue. In many instances we can see that the consonants marked either belong to words which demonstrate no phonetic iconism - at least not in their modern phonetic shape - as in словно, наши, но, на, них, новизной, or if they do perform an iconic function as, possibly, in cmapble, where some etymologists relate the root with that in the English words stark and perhaps strong, their supposed phonetic meaning (reflection of a muscular strain) is completely unrelated, if, indeed, is not opposite, to their meaning in the text. Thus we see that when phonetic iconism is a property of a text and not of an isolated word it is the result of a joint performance of many sounds of many different words. Both the motive for iconicity and the means of its realization belong to the text as a supraverbal unity and not to the individual words.

While phonic iconism of a word belongs to it as its biographical feature, as it were, the sound-sense unity of a text is built by joining into one iconic picture the phonetic features of many words whose individual relations with the sound-symbolic universe may be random and/or nebulous. The phonic iconicity of a word is its paradigmatic property, joining words vertically into lists with similar phonoiconic meanings to form classes which are there for as long as the words in question remain in the language. The phonic iconicity of a text, however, arranges words horizontally into ad hoc syntagmatic chains as members of one team, working simultaneously with one semantic task to perform - in all probability never to meet in one text again. It means that the phonic iconicity of a word belongs to langue while the phonic iconicity of a text is a phenomenon of parole. But in both cases the sounds of a language serve their purpose not as realizations of whole phonemes but as possessers of particular phonetic features.

\section{Conclusion}

Thus we see that in any instance of phonic iconism, whether relating to an iconic word or to a case of sound-symbolism in a text, the linguistic unit that performs the concrete iconic function is the phonotype and not the phoneme in the entirety of its features. The phonotype is the type of speech sound characterized by a concrete phonetic feature specific for the particular type of meaning designated. This specificity is based on the similarity between the referent feature chosen as the motive for designation and the feature of the phoneme suitable for the function of designation. As S. Voronin has shown (Cf. Voronin 1982), the phonotype may unite speech sounds which in classical phonetics or phonology are principally separate, namely vowels and consonants. We have seen it happen in the case of the labial phonotype uniting /u/, /o/, /b/ and $/ \mathrm{p} /$. Another case is the phonotype of high front sounds, uniting /i/ and palatal consonants to designate small objects or expressing endearment, especially in speaking to children or in children speech. As example consider the case when a Russian girl of three invented a name for any very small object she could see in front of her on the table, say, a bread crumb or a miniature piece of a thread, etc. She would move the object with her tiny finger and comment: тизя, тизяка /t'iz'a/, /t'iz'aka/ (with the stress on the first syllable in тизя, and on the second in тизяка). So each time when a phoneme as a speech sound serves a phonoiconic function it enters a group of speech sounds united for the 
particular case of nomination (or - in the case of feature characterized by similarity with a feature a text - designation) by one particular phonetic in the object of designation.

\section{References}

Shamina, E.A. (1989). Distributsiya Labialnykh $v$ foneticheskom $i$ fonosemanticheskom otnoshenii: avtoref. dis....kand. filologicheskikh nauk [Distribution of the Labials from the Point of View of Phonetics and Phonosemantics].Cand. Diss. Phil. Abstract. Leningrad, LGU, 16 p.

Slonitskaya, E.I. (1987). Zvukosimvolism oboznacheniy okruglogo (Opyt tipologicheskogo issledovaniya): avtoref. dis....kand. filologicheskikh nauk [Sound Symbolism in Designations of Rounded Objects. A Case in Typological Research]. Cand. Diss. Phil. Abstract. Leningrad, LGU, $16 \mathrm{p}$.

Voronin, S.V. (1969). Anglijskie onomatopy (Tipy i Strojenie): avtoref. dis. ... kand. filologicheskikh nauk [English Onomatopes (Types and Structure)]. Cand. Diss. Phil. Abstract. Leningrad, LGU, $16 \mathrm{p}$.

Voronin. S.V. (1998). Anglijskie onomatopy. Fonosemanticheskaya klassifikatsiya [English Onomatopes: A Phonosemantic Classification]. St. Petersburg, Institut Inostrannykh Yazykov, 196 p.

Voronin, S.V. (1982). Osnovy fonosemantiki [Fundamentals of Phonosemantics]. Leningrad, LGU, $244 \mathrm{p}$.

Voronin, S.V. (2005). Iconicity. Glottogenesis. Semiosis. (Sundry Papers). St. Petersburg, SPbGU, $147 \mathrm{p}$.

Zhuravlev, A.P. (1974). Foneticheskoye Znacheniye [The Sense of the Sound]. Leningrad, LGU, $160 \mathrm{p}$.

\section{Фонема и фонотип}

О.И. Бродович

Институт иностранных языков Россия, 199178, Санкт-Петербург, Васильевский остров, 12-я линия, д. 13

\footnotetext{
Целью статьи является доказательство того факта, что в феномене звукоизобразительности участвуют не цельные фонемы в совокупности своих релевантных признаков, но именно отдельные признаки, объединяющиеся в фонотипы. В статье также обсуждается сходство и различие звукоизобразительности слова и текста.
}

Ключевые слова: иконичность, звуковой символизм, ономатопея, звуковая палитра текста, соотношение звучания и значения.

Научная специальность: 10.00.00 - филологические науки. 